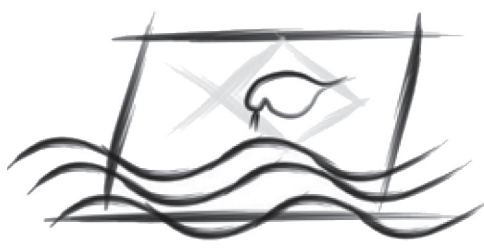

J. Braz. Soc. Ecotoxicol., v. 5, n. 1, 2010, 63-70

doi: $10.5132 /$ jbse.2010.01.011

ECOTOX - Brazil

\title{
Phytoplanktonic Structure and Chemistry of the Water in the Monjolinho Reservoir (SP, Brazil) During a Cyanobacterial Bloom Episode
}

\author{
R. B. Sotero-Santos ${ }^{1 *}$, M. J. Dellamano-Oliveira ${ }^{2}$, E. G. Carvalho ${ }^{1}$, A. Minillo ${ }^{3} \&$ O. Rocha ${ }^{1}$ \\ ${ }^{1}$ Departamento de Ecologia e Biologia Evolutiva, Centro de Ciências Biológicas e da Saúde, \\ Universidade Federal de São Carlos - UFSCar, Rod. Washington Luis, Km 235, CEP 13565-905, São Carlos - SP, Brazil \\ ${ }^{2}$ Laboratório de Ficologia, Departamento de Botânica, Centro de Ciências Biológicas e da Saúde, \\ Universidade Federal de São Carlos - UFSCar, Rod. Washington Luis, Km 235, CEP 13565-905, São Carlos - SP, Brazil \\ ${ }^{3}$ Centre of Water Resources and Applied Ecology, Department of Hydraulic and Sanitation, Engineering School of \\ São Carlos, University of São Paulo - USP, Av. Trabalhador São Carlense, 400, CEP 13566-590, São Carlos - SP, Brazil
}

(Received June 19, 2009; Accepted October 1, 2009)

\begin{abstract}
The composition of the phytoplankton and parameters of the water quality were studied in a tropical reservoir during cyanobacterial bloom episode. Samples were collected at two sites during October 2004. The phytoplankton community consisted of 69 taxa, distributed into 9 classes. Most taxa belonged to Cyanobacteria (17), Chlorophyceae (21), Bacillariophyceae (8), Conjugatophyceae (7), Dinophyceae (1), Chrysophyceae (4), Euglenophyceae (9), Cryptophyceae (1) and Xanthophyceae (1). Anabaena circinalis Rabenhorst ex Bornet et Flahault e Anabaena spiroides Klebahn were the dominant species. Statistical analyses revealed significant spatial variation $(\mathrm{p}<0.05)$ between sampling points only for $\mathrm{N}$ compounds and chlorophyll $a$. Most limnological variables analyzed showed no significant temporal variation $(\mathrm{p}>0.05)$. Cyanobacteria bloom was concomitant with the following environmental conditions, warm water temperatures $\left(19\right.$ to $22^{\circ} \mathrm{C}$ ), periods of water column stability and high concentrations of $\mathrm{N}\left(724.9 \mu \mathrm{g} . \mathrm{L}^{-1}\right)$ and $\mathrm{P}\left(90.9 \mu \mathrm{g} . \mathrm{L}^{-1}\right)$ in the reservoir and $\mathrm{NH}_{4}$ as being the predominant nitrogen compounds. It is speculated that those conditions could play a role in the dominance of cyanobacteria.
\end{abstract}

Keywords: Anabaena circinalis, Anabaena spiroides, cyanotoxins, phytoplankton community, toxic bloom.

\section{RESUMO}

\section{Estrutura Fitoplanctônica e Química da Água na Represa do Monjolinho (SP) Durante uma Floração de Cianobactérias}

A composição do fitoplâncton e parâmetros da qualidade da água foram estudados em um reservatório tropical durante uma floração de cianobactérias. As amostras foram coletadas em dois pontos do reservatório durante o mês de outubro de 2004. A comunidade fitoplanctônica consistiu de 69 taxa, distribuídos em 9 classes. A maioria dos taxa pertenceu à Classe Cyanobacteria (17) e Chlorophyceae (21), seguidas por Bacillariophyceae (8), Conjugatophyceae (7), Dinophyceae (1), Chrysophyceae (4), Euglenophyceae (9), Cryptophyceae (1) e Xanthophyceae (1). Anabaena circinalis Rabenhorst ex Bornet et Flahault e Anabaena spiroides Klebahn foram as espécies dominantes no reservatório. As análises estatísticas indicaram variação espacial significante $(\mathrm{p}<0,05)$ entre os pontos de amostragem apenas para os compostos nitrogenados e clorofila- $a$. A maioria das variáveis limnológicas analisadas não indicou qualquer variação temporal $(\mathrm{p}>0,05)$. A floração de cianobatérias foi concomitante com as seguintes condições ambientais: valores relativamente elevados na temperatura da água $\left(19\right.$ a $\left.22{ }^{\circ} \mathrm{C}\right)$, períodos de estabilidade na coluna d'água e altas concentrações de $\mathrm{N}\left(724,9 \mu \mathrm{g} . \mathrm{L}^{-1}\right)$ e $\mathrm{P}\left(90,9 \mu \mathrm{g} . \mathrm{L}^{-1}\right)$ na represa e $\mathrm{NH}_{4}$ como a forma predominante entre os compostos nitrogenados. Especula-se que estas condições poderiam favorecer a dominância das cianobactérias.

Palavras-chave: Anabaena circinalis, Anabaena spiroides, cianotoxinas, comunidade fitoplanctônica, floração tóxica.

*Corresponding author: Dr. Rosana Barbosa Sotero-Santos, e-mail: rmabarb@yahoo.com.br 


\section{INTRODUCTION}

The growth of cyanobacterial populations, especially those attaining a high biomass, has been increasingly reported around the world. There is general concern about public health and the environment given the likely effects of global warming, especially regarding unpredictable responses of those species that produce toxins (Aboal; Puig 2005) considering that both moderate and high temperatures tend to favour the occurrence of blooms. Cyanobacteria often dominate phytoplankton communities under certain conditions such as: nutrient-enriched waters and warm temperatures (ranging from 15 to $30^{\circ} \mathrm{C}$ ). Additionally water column stability, mild or absent winds, low turbulence are other favourable environmental conditions to cyanobacterial blooming. Morphometry of aquatic systems, low grazing rates by large zooplankton have been considered advantageous conditions for the development of those kinds of bloom as well (Mur et al., 1999; Zurawell et at. 2005).

Blooms of various species of cyanobacteria occur frequently as a consequence of eutrophication of aquatic environments. Cyanobacterial blooms have adverse effects on aesthetics and recreation. They are also linked with a number of other water-related problems including bad-smelling, non-potability, and fish kills due to oxygen depletion and ammonia release as the cyanobacteria decomposition proceeds (Chorus et al., 2000; Smith et al., 2008). Moreover, seasonal growth of cyanobacteria also interferes with drinking water treatment processes (Alam et al. 2001; Watson et al. 2007).

Freshwater blooms of cyanobacteria commonly produce toxins which can be classified in five functional groups: hepatotoxins, neurotoxins, cytotoxins, dermatotoxins and irritant toxins (lipopolysaccharides) (Wiegand; Pflugmacher, 2005). Among the hepatotoxins, the microcystins are the most frequently detected. The chemical structures and mode of action of these cyanotoxins, mainly microcystins, nodularin and anatoxins have been extensively described in the literature (Zurawell et al., 2005; Wiegand; Pflugmacher 2005). Similarly, several observations of the effects of these toxins to various animals (including humans) have also been broadly reported (Zurawell et al. 2005; Wiegand; Pflugmacher, 2005; Ibelings; Chorus, 2007).

Cyanobacterial blooms are a common occurrence in Brazilian reservoirs since most of them are characterized as eutrophic or hypereutrophic (Calijuri et al., 2002; DellamanoOliveira et al., 2008; Tundisi et al., 2008). Despite the frequency of episodes of cyanobacterial blooms in Brazil, there is few data or information about the structure of the phytoplankton, zooplankton communities and toxicological features during the occurrence of toxic blooms (Sotero-Santos et al., 2006). Additionally, the means by which environmental factors influence cyanotoxin production are weakly understood. Though nutrients have long been assumed as a contributing factor to both cyanobacterial abundance and toxin production, surprisingly few information has been published on how, for example, alterations in phosphorus and nitrogen may change microcystin production (Kotak et al., 2000).
The present study described some aspects of the structure of the phytoplankton community and chemistry of water in Monjolinho Reservoir (21 $59^{\prime} 8.4^{\prime \prime} \mathrm{S}$ and $47^{\circ} 52^{\prime} 45^{\prime \prime} \mathrm{W}$ ) during a brief episode of Anabaena bloom. Toxin analyzes and toxicity to aquatic organisms (cladocerans) and to mammals (mice) were also investigated and confirmed. Details about the toxicological features of bloom were described previously (Sotero-Santos et al., 2008). The Monjolinho Reservoir is considered a eutrophic system which receives continuous nutrient inputs directly through a poultry industry and indirectly from agricultural fields. This reservoir was studied previously as reported by Hino et al. (1984), Nogueira and Tundisi (1994) and Seleghim and Godinho (2004). The present study reports the first occurrence of cyanobacteria bloom in this productive system.

\section{MATERIALS AND METHODS}

\section{Study site description}

The site of this study is a shallow, artificial reservoir located in the São Carlos city, São Paulo State, Brazil. It was formed by the damming of the Monjolinho River. The main morphometric and hydrological characteristics of Monjolinho Reservoir are: area $=47.157 \mathrm{~m}^{2}$, volume $=73.251 \mathrm{~m}^{3}$, $\max$ depth $=3 \mathrm{~m}$, mean depth $=1.54 \mathrm{~m}$, max length $=510 \mathrm{~m}$, max width $=150 \mathrm{~m}$ and water retention time varying between about 2 (rainy season) and 23 days (dry season) (Nogueira; Tundisi, 1994).

\section{Properties of reservoir water and phytoplankton sampling}

Sampling was carried out three times per week during October 2004, at two sites in the reservoir: S-1 (near inflow of river) and S-2 (near the dam) from 10:00 - 12:00 hours in the morning. To evaluate the water quality, samples for laboratory analysis were collected at the surface of the water. Simultaneously, in situ measurements of temperature, $\mathrm{pH}$, conductivity and dissolved oxygen (DO) were performed in the water column, using a Horiba U-10 multi-probe (Horiba, Co., Japan). Water transparency was estimated from Secchi Disk readings.

Analyses of nitrate $\left(\mathrm{NO}_{3}\right)$, nitrite $\left(\mathrm{NO}_{2}\right)$, ammonium $\left(\mathrm{NH}_{4}\right)$ concentrations, total dissolved phosphate (TDP), organic (TOP) and inorganic phosphate (TIP), and total organic nitrogen (TN) concentrations were performed in the laboratory following the procedures described in Koroleff (1976), Golterman et al. (1978) and Mackereth et al. (1978), while total organic phosphorus (TP), was determined as recommended by APHA (1995). Chlorophyll $a$ and silicon as soluble reactive silicon (SRSi) were determined as by Nush (1980) and Golterman et al. (1978), respectively.

Qualitative analysis of phytoplankton was performed on samples collected with conical plankton net of $20 \mu \mathrm{m}$ mesh size and samples were preserved in $4 \%$ formaldehyde solution. Taxonomic identification was performed down to the lowest possible level, mostly to species, using an Axiovert 
Zeiss microscope with 2560 maximum magnification and consulting specialized literature. The classification system used for diatoms (Bacillariophyceae) was that of Round et al. (1990); for Cyanophyceae, Anagnostidis \& Komárek (1988, 1989) and Komárek \& Anagnostidis (1999); and for other groups, Hoek et al. (1995).

For quantitative analysis, samples were collected in Van Dorn bottles at the surface level $( \pm 50 \mathrm{~cm}$ depth, considering that the water column was not thermally stratified) and fixed in Lugol's preservative. Populations were counted under an inverted microscope (Zeiss) at a magnification of $400 \mathrm{X}$, using Utermöhl's method (Utermöhl, 1958). Settled sample volumes varied from 2 to $10 \mathrm{~mL}$, depending on organism density. Sedimentation time was at least 3 hours (Wetzel; Likens, 1991). The individuals (cells, colonies, cenobia and filaments) were counted in random fields and densities were calculated as recommended by APHA (1995). Relative abundance was estimated in accordance with criteria proposed by Lobo and Leighton (1986) and community richness was evaluated as the total number of species found during the whole study. The specific diversity calculation was based on the Shannon and Wiener index (Shannon; Weaver, 1963). The equitability or uniformity $(\mathrm{J})$ was evaluated by the method described by Pielou (1975). In order to identify significant temporal and spatial differences between the limnological variables (abiotic and biotic) at the sampling stations (S-1 and S-2) the Tukey parametric test was employed when the distribution was normal (ANOVA one-way) or the Kruskall-Wallis non-parametric, if not (with significant level, $\alpha=0.05$ ).

\section{RESULTS AND DISCUSSION}

In the current study, changes in the color of the reservoir water were first noticed in the beginning of October, 2004 and an inspection of phytoplankton net-samples revealed the presence of a cyanobacterial bloom that was dominated by Anabaena circinalis Rabenhorst ex Bornet et Flahault and Anabaena spiroides Klebahn. Neither phytoplankton nor physical and chemical variables had regularly been monitored in the previous months. For this reason the interpretation of reservoir conditions was limited to the period of establishment, full development and decay of the Anabaena bloom, a period extending from October $6^{\text {th }}$ to November $10^{\text {th }}, 2004$.

The phytoplankton community consisted of 69 taxa distributed in 9 classes. Most taxa belonged to the following taxonomic classes: Cyanobacteria (24.6\%), Chlorophyceae (30.4\%), Euglenophyceae (13.0\%), Bacillariophyceae (11.6\%) and Conjugatophyceae (10.1\%). Other groups poorly represented were: Chrysophyceae (8.8\%), Dinophyceae (1.4\%), Cryptophyceae (1.4\%) and Xanthophyceae (1.4\%) (Figure 1). The mean value of the total phytoplankton density varied between $3.4 \times 10^{5}$ ind. $\mathrm{mL}^{-1}$ (site 1) and $1.3 \times 10^{6}$ ind. $\mathrm{mL}^{-1}$ (site 2). Anabaena circinalis and A. spiroides Klebahn were dominant (in the majority of samples) in the phytoplankton community during October 2004 (Figure 2). Phytoplankton succession in this reservoir was first described by Nogueira and Tundisi (1996) and Seleghim and Godinho (2004) which reported the
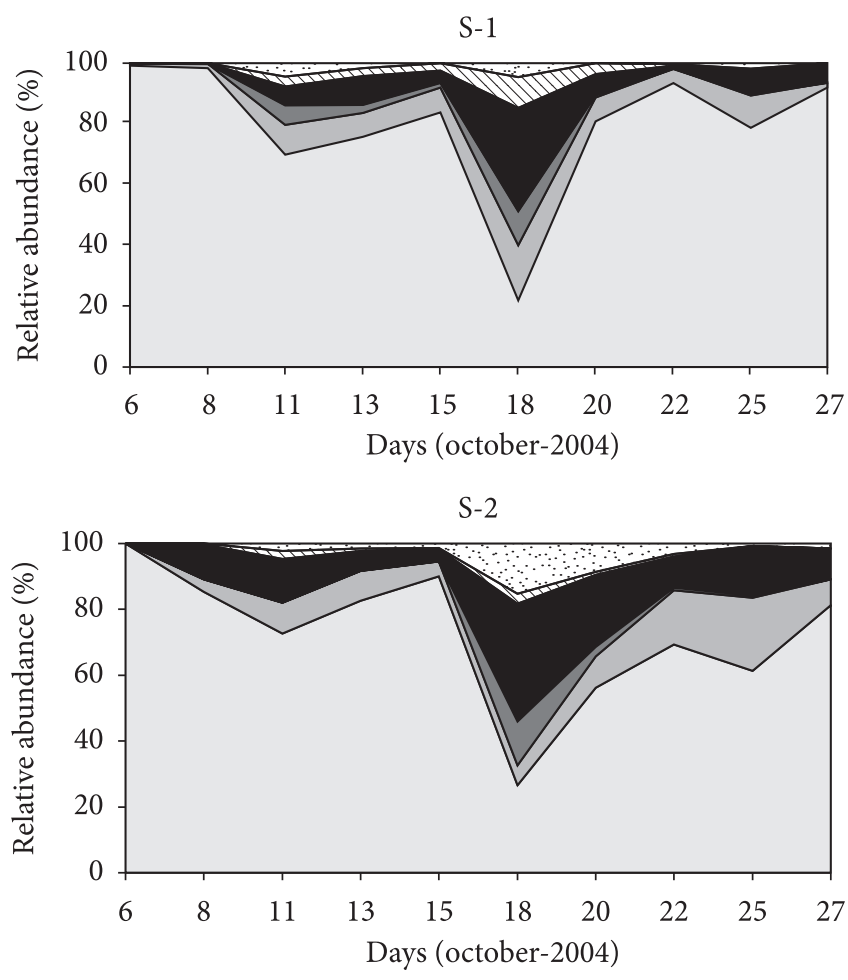

\begin{tabular}{|l}
$\square$ Cyanophyceae $\square$ Bacillariophyceae $\square$ Conjugatophyceae \\
$\square$ Chlorophyceae $₫$ Euglenophyceae $\square$ Others
\end{tabular}

Figure 1 - Relative abundance of phytoplankton at site 1 (near the river inflow) and site 2 (near the dam) of Monjolinho reservoir, expressed as percentages.

dominance of diatoms (Aulacoseira granulata and A. italica) during the dry season, replaced by chrysophyceans (mainly Dinobryon sp and Synura elegans) in October-November and a later replacement by chlorophyceans after the heavy rainfalls in December and January months.

Figure 3 shows that during the period of this study the climate in the region was characterized by moderate precipitation (total precipitation $=128 \mathrm{~mm}$ and mean $=4.2 \mathrm{~mm}$ ), low mean wind velocities (mean value $=3.1 \mathrm{~m} . \mathrm{s}^{-1}$ ) and warm temperatures $\left(17.5-22.0^{\circ} \mathrm{C}\right)$. Precipitation ranged from 0 to $14 \mathrm{~mm}$ per day and maximum wind velocity was $6.8 \mathrm{~m} \cdot \mathrm{s}^{-1}$. Typical conditions of a tropical spring (October) in the Southeast of Brazil include a transition period between the dry and wet periods with low turbulence in the water and relatively higher residence time when compared to winter (highest wind velocities) and summer conditions (higher temperatures and intense rainfalls). In concordance with our observations, Tundisi et al. (2008) reported that the hydrology of the basin, retention time of the reservoir and cold fronts have had an impact in the vertical and horizontal structure of the Barra Bonita Reservoir which promoting rapid changes in the planktonic community and in the succession of species. In that reservoir, blooms of Microcystis sp. have been recurrent during periods of stability.

Cyanobacteria were the best represented group in terms of relative abundance in the majority of the samples collected in both sampling sites. On the other hand, the occurrence of the first rainfalls in October induced changes in the abundance 
S1

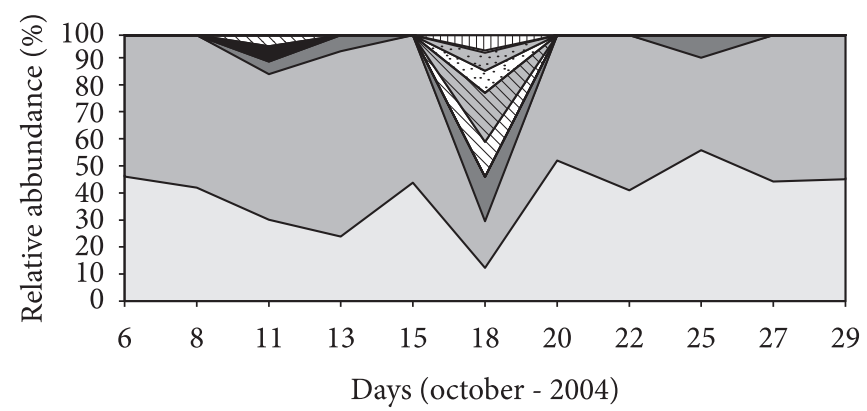

S2

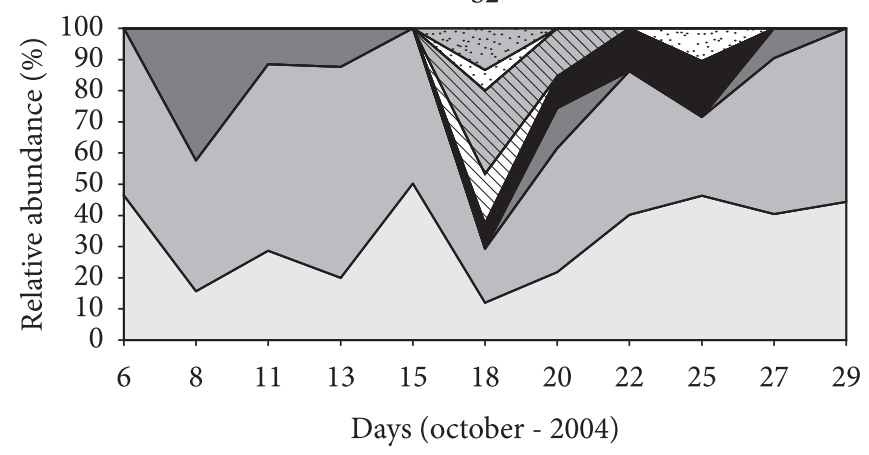

Days (october - 2004)

\begin{tabular}{|ll|}
\hline$\square$ Anabaena circinalis & $\square$ Anabaena spiroides \\
$\square$ Free cells of Microcystis sp. & $\square$ Aulacoseira granulata \\
$\square$ Staurodesmus sp. 1 & $\square$ Crucigenia tetrapedia \\
$\square$ Pediastrum duplex & $\square$ Peridinium sp. \\
\hline
\end{tabular}

Figure 2 - Relative abundance (\%) of the dominant species in the phytoplankton community in Monjolinho Reservoir (sites 1 and 2) during October 2004.
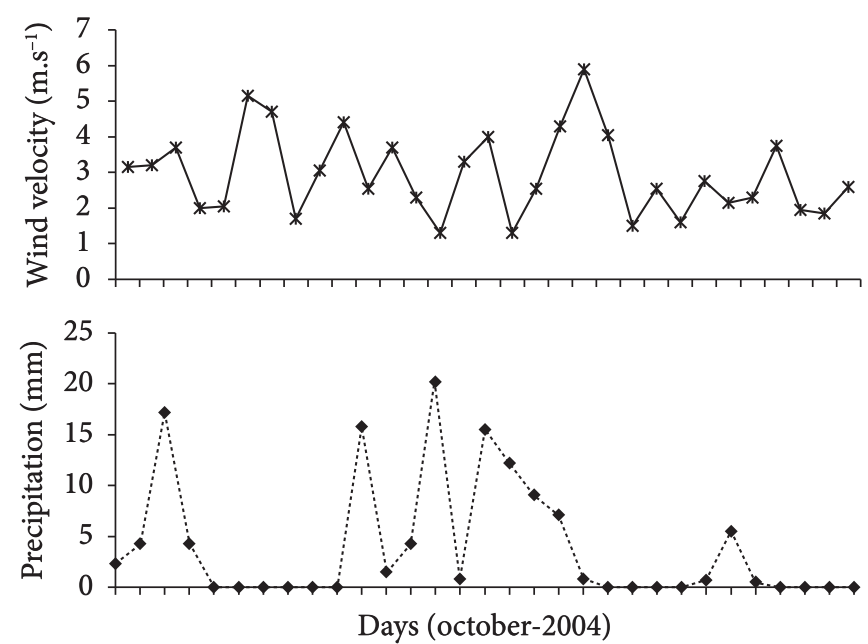

Figure 3 - Wind velocities $\left(\mathrm{m} . \mathrm{s}^{-1}\right)$ and precipitation $(\mathrm{mm})$ registered in a Monjolinho Reservoir.
Cyanobacteria (Figure 1-3). However, the dominant total algal densities decreased markedly after consecutive days of rainfall, particularly in the period between $11^{\text {th }}$ and $18^{\text {th }}$ of October (Figure 3). The number of species (richness) and the diversity indices are presented in Figure 4. The highest richness and diversity occurred at site 1 .

Data about quality of water show that temperature of the water in the reservoir varied from 19 to $22{ }^{\circ} \mathrm{C}$, slowly rising over the spring. Warm water temperatures (about $20^{\circ} \mathrm{C}$ ) are typical for the beginning of the rainy season in this tropical area and are considered favourable for the growth of phytoplankton. Water $\mathrm{pH}$ varied widely, from slightly acid to basic (5.86 to 9.45). Similarly, dissolved oxygen concentrations varied from 4.89 to $14.43 \mathrm{mg} . \mathrm{L}^{-1}$ (data not presented). High concentrations of DO are also common during the occurrence of bloom due to intense photosynthetic activity. Both $\mathrm{pH}$ and DO values were expected because these parameters are related to photosynthetic activities of the cyanobacterial bloom and other green-algae as well (Sotero-Santos et al., 2008). Cyanobacteria and phytoplankton blooms are likely to increase the $\mathrm{pH}$ when they take up $\mathrm{CO}_{2}$.

Table 1 displays the mean values and standard deviations for nutrients ( $\mathrm{N}$ and $\mathrm{P}$ compounds), chlorophyll $a$ and SRSi concentrations in the surface water of Monjolinho Reservoir, from the two sampling sites (S-1 and S-2). Measurements of these variables were performed only at the surface level since the water column was homogeneous during most of the study period as evidenced by the temperature profile (Figure 5) and the reservoir is shallow (max depth $=3 \mathrm{~m}$ ). Seleghim and Godinho (2004) have stated that there is no persistent thermal or density stratification in a shallow reservoir, such as Monjolinho.
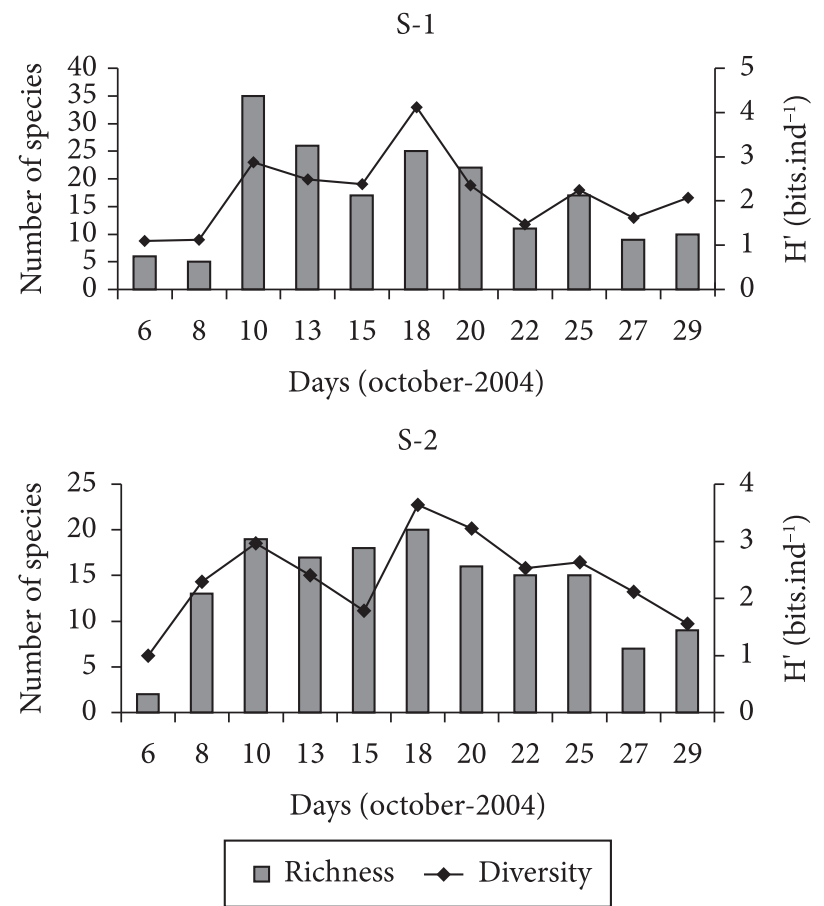

Figure 4 - Richness and diversity (bits.organisms ${ }^{-1}$ ) variation in the phytoplankton community in Monjolinho Reservoir (site 1 and 2) during October 2004. 
High nutrient concentrations were observed in the reservoir. Elevated nitrogen and phosphorus loadings revealed its intense trophic state, which is comparable to other eutrophic reservoirs such as Barra Bonita (Tundisi et al., 2008). In Monjolinho reservoir, nutrient inputs have been attributed to punctual (organic-industrial effluents) and non-punctual (agricultural runoff) sources. Additionally, untreated domestic sewage was

Table 1 - Mean values and standard deviations (SD) for nutrients ( $\mathrm{N}$ and P compounds, in $\left.\mu \mathrm{g} . \mathrm{L}^{-1}\right)$, chlorophyll $a\left(\mu \mathrm{g} . \mathrm{L}^{-1}\right)$ and soluble reactive silica (mg.L $\left.\mathrm{L}^{-1}\right)$ concentrations in the surface water of Monjolinho Reservoir during October 2004, in the sites S-1 and S-2. $\left(\mathrm{NO}_{2}\right.$ : nitrite; $\mathrm{NO}_{3}$. nitrate; $\mathrm{NH}_{4}$ : ammonium; TN: total nitrogen; TDP: total dissolved phosphate; TIP: total inorganic phosphate; OP: total organic phosphate; TP: total phosphorus; SRSi: soluble reactive silica; TN/TP: total nitrogen and total phosphorus ratio and $\mathrm{Chl} a$ : chlorophyll $a$ ).

\begin{tabular}{ccc}
\hline Variables & Sites & Mean and SD \\
\hline $\mathrm{NO}_{2}{ }^{-}$ & $\mathrm{S} 1$ & $15.4 \pm 6.6$ \\
$\mathrm{NO}_{3}$ & $\mathrm{~S} 2$ & $8.2 \pm 2.6$ \\
& $\mathrm{~S} 1$ & $49.9 \pm 19.3$ \\
$\mathrm{NH}_{4}$ & $\mathrm{~S} 2$ & $28.9 \pm 12.5$ \\
& $\mathrm{~S} 1$ & $128.7 \pm 93.3$ \\
$\mathrm{TN}$ & $\mathrm{S} 2$ & $39.2 \pm 25.6$ \\
& $\mathrm{~S} 1$ & $724.9 \pm 158.0$ \\
$\mathrm{TDP}$ & $\mathrm{S} 2$ & $881.5 \pm 289.1$ \\
& $\mathrm{~S} 1$ & $31.3 \pm 12.0$ \\
$\mathrm{TIP}$ & $\mathrm{S} 2$ & $27.5 \pm 6.7$ \\
& $\mathrm{~S} 1$ & $21.0 \pm 12.0$ \\
$\mathrm{TOP}$ & $\mathrm{S} 2$ & $13.5 \pm 4.5$ \\
& $\mathrm{~S} 1$ & $10.3 \pm 9.4$ \\
$\mathrm{TP}$ & $\mathrm{S} 2$ & $14.0 \pm 2.9$ \\
& $\mathrm{~S} 1$ & $90.9 \pm 25.8$ \\
$\mathrm{SRSi}$ & $\mathrm{S} 2$ & $104.1 \pm 27.3$ \\
& $\mathrm{~S} 1$ & $6.1 \pm 1.1$ \\
$\mathrm{TN} / \mathrm{TP}$ & $\mathrm{S} 2$ & $6.5 \pm 0.7$ \\
& $\mathrm{~S} 1$ & $8.2 \pm 1.7$ \\
$\mathrm{Ch} a$ & $\mathrm{~S} 2$ & $8.4 \pm 1.5$ \\
& $\mathrm{~S} 1$ & $39.1 \pm 38.1$ \\
& $\mathrm{~S} 2$ & $91.7 \pm 54.9$ \\
\hline
\end{tabular}

being accidentally discharged into the reservoir due the rupture of sewage pipe and obviously that fact also contributed to increase the nutrient levels in the reservoir in October 2004. Concentration of nutrients available for algal or cyanobacterial growth exhibited a temporal and significant variation and it showed difference among the sampling sites.

Ammonium and nitrate mean concentrations in the upper part of the reservoir, at site S-1 (128.7 \pm 93.3 and $49.9 \pm$ $19.3 \mu \mathrm{g} . \mathrm{L}^{-1}$, respectively) were much higher than the values recorded in the lower part of the reservoir near the dam, at site S-2 (39.2 \pm 25.6 and $28.9 \pm 12.5 \mu \mathrm{g} \mathrm{L}^{-1}$, respectively). The nitrogen analyses indicated that ammonium was the predominant nitrogen form in the Monjolinho reservoir in both sites. It is speculated that both Anabaena species could take advantage over other phytoplanktonic species through their ability to uptake ammonium. Cyanobacteria have been considered able to use nitrate, nitrite and ammonium as inorganic source of nitrogen by the so as $\mathrm{N} 2$ from N-fixing Cyanobacteria. However, when ammonium is available, it seems that these organisms do not assimilate others inorganic source of nitrogen (Ochoa-de-Alda et al., 1996). According to Von Rückert and Giani (2004) Cyanobacteria may compete with eukaryotes for nitrate and they also have better ability to the rapid use of ammonium when nitrate is no longer available in the environment, thus allowing them to suddenly increase their population and develop into a bloom.

Variations in phosphate data were not as clear as observed for nitrogen compounds. Inorganic phosphate mean concentration at site S-1 $\left(21.0 \pm 12.0 \mu \mathrm{g} . \mathrm{L}^{-1}\right)$ was higher than that observed at site $\mathrm{S}-2\left(13.5 \pm 4.5 \mu \mathrm{g} . \mathrm{L}^{-1}\right)$, but that tendency was not verified for organic phosphate where both sites exhibited concentrations relatively similar $\left(10.3 \pm 9.4 \mu \mathrm{g} . \mathrm{L}^{-1}\right.$ at site S-1 and $14.0 \pm 2.9 \mu \mathrm{g} . \mathrm{L}^{-1}$ at site S-2). On the other hand the total nitrogen $\left(724.9 \pm 158.0 \mu \mathrm{g} . \mathrm{L}^{-1}\right.$ at site $\mathrm{S}-1$ and $881.5 \pm 289.1 \mu \mathrm{g} . \mathrm{L}^{-1}$ at site S-2) and total phosphorus (90.9 $\pm 25.8 \mu \mathrm{g} . \mathrm{L}^{-1}$ at site S-1 and $104.1 \pm 27.3 \mu \mathrm{g} . \mathrm{L}^{-1}$ at site S-2), which reflect both, nutrient available in the water plus the amount incorporated in biomass were only slightly lower in the upper part than near the dam.

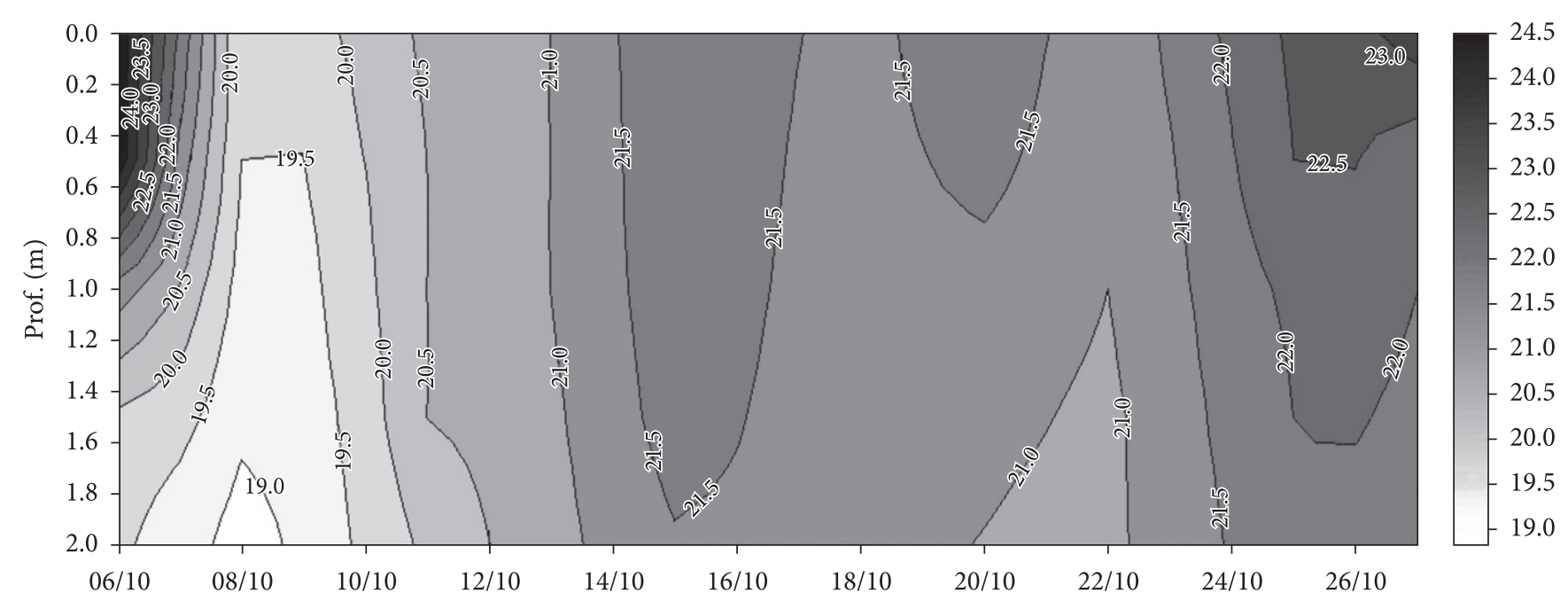

Figure 5 - Isopleths of temperature $\left({ }^{\circ} \mathrm{C}\right)$ registered in a Monjolinho Reservoir during October 2004 in the S-2 station. 
Total nitrogen/total phosphorus ratio greatly changed along the bloom occurrence (Table 1). The ratios were low at the beginning of the bloom, decreasing further after the occurrence of rainfalls triggering a change in the cyanobacteria dominance and returned to the initial levels at the end of the bloom (Figure 6). Phosphorus concentrations were particularly high at the time of the bloom establishment with N:P ratios around 8.0 (Table 1). Blooms of cyanobacteria are usually associated with stable conditions and high nutrient concentrations (Giani et al., 2005). Nitrogen-fixing species such as those of Anabaena genus have been found to be especially associated with high phosphorus availability (Smith, 1983; Downing et al., 2001). Low N:P ratio has been considered as a stimulatory factor to cyanobacterial


blooms among other conditions such as water column stability and presence of gas vacuoles in the majority of cyanobacteria cells (Mur et al., 1999). According to Reynolds (1999), the crucial factor for cyanobacterial dominance, comes from its ability to remain in suspension by regulating buoyancy and responding rapidly to favourable nutritional conditions.

Chlorophyll mean concentrations at site S-1 $\left(39.1 \pm 38.1 \mu \mathrm{g} . \mathrm{L}^{-1}\right)$ were much lower than at site S-2. $\left(91.7 \pm 54.9 \mu \mathrm{g} . \mathrm{L}^{-1}\right)$. That fact was expected because cyanobacterial scum tend to be concentrated near to the shores and around the dam due water flux and wind action. Consequently, chlorophyll- $a$ concentrations at S-2 could be overestimated when compared with to other parts of the reservoir. Statistical analyses revealed significant

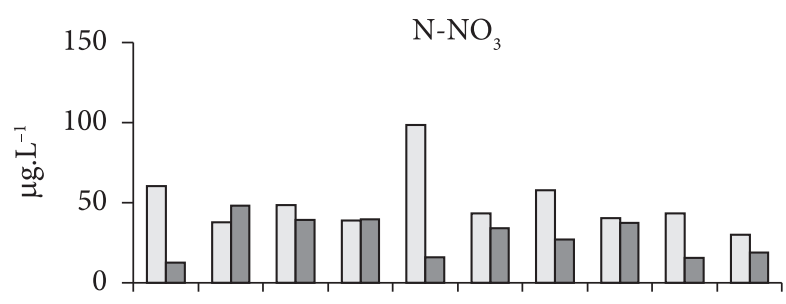

DTP
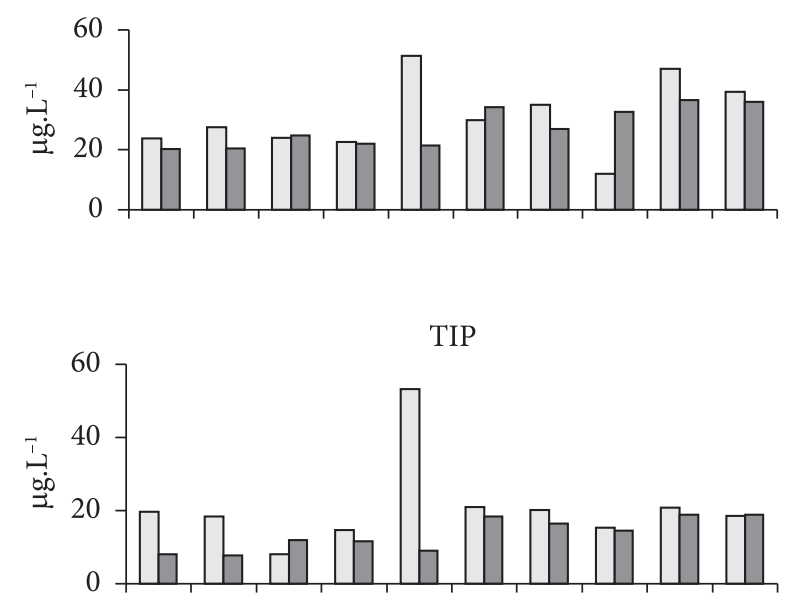

$\mathrm{TP}$

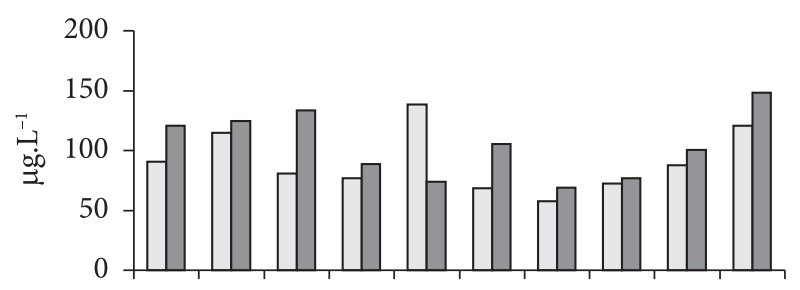

TN/TP

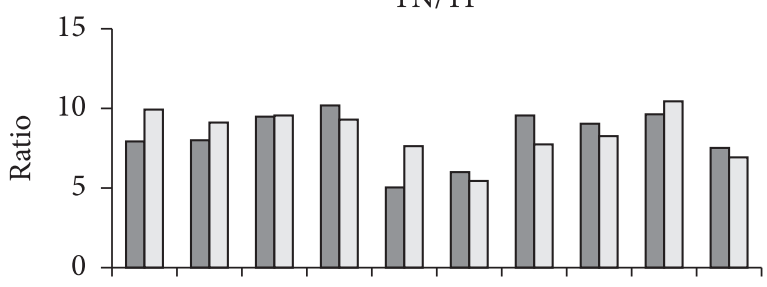

Figure 6 - Concentrations of nutrients $\left(\mu \mathrm{g} . \mathrm{L}^{-1}\right)$ and SRSi $\left(\mathrm{mg} \cdot \mathrm{L}^{-1}\right)$ in the surface water of Monjolinho Reservoir during October 2004, in stations S-1 and S-2 $(\mathrm{S}-1=$ bar black, near the river inflow and $\mathrm{S}-2=$ bar gray, near the dam). 
spatial variation $(\mathrm{p}<0.05)$ between sampling points only for nitrogen compounds and chlorophyll $a$. Most limnological variables analyzed showed no significant temporal variation $(\mathrm{p}>0.05)$, except for temperature, $\mathrm{pH}, \mathrm{DO}$ and SRSi. Water transparency varied between 20 and $50 \mathrm{~cm}$ (data not presented) but no correlation was found between Secchi readings and chlorophyll $a$ concentrations.

Climate events and physical and chemical conditions driven by them appear as forcing functions that favor the bloom. Historically, the dominant climate conditions in Monjolinho Reservoir during August and September months has been characterized by the highest wind velocities in the year and rising temperatures from September onwards. A wind force of $6 \mathrm{~m} / \mathrm{s}$ has been suggested as sufficient to promote turbulence in the whole water column, or at least in a great volume of the reservoir with important mixing consequences on the vertical distribution of dissolved oxygen, turbidity, and water temperature (Tundisi et al., 2002). In the present study, climate events were somewhat different in 2004 (see Figure 3). It is speculated that a combination of moderate winds and increasing temperatures in early October allowed thermal stratification development in the Monjolinho Reservoir, possibly favoring the growth of Anabaena. Moreover, the Monjolinho Reservoir has been considered plenty of nutrients round the year (Bianchini; Antônio, 2000), as also observed for the majority of the shallow eutrophic and tropical systems. Our results suggested that nutrient loading, warm water temperature and water column stability were relevant environmental factors that influenced cyanobacterial dominance in the Monjolinho Reservoir. Anabaena species are also favored in low mixing depth ratios $(\mathrm{Zm}<1)$.

Anabaena species are S-strategists (Reynolds, 1997) being stimulated to grow under high light intensities and thermal stability. A delay of the rainfalls with prolonged reservoir stability coupled with nutrient availability and increasing temperature seem to be the combination of weather events and/or physical and chemical factors that triggered the unusual growth of Anabaena populations in Monjolinho Reservoir. The arrival of rainfalls by middle October induced temperature drop, nutrient dilution and wash-out and broke up the thermal stratification. Although Anabaena spp. was still dominant, other groups of algae such as chlorophyceans and diatoms increased their abundance. On the other hand, the Anabaena bloom was quickly re-established as soon as rainfall stopped and stable conditions returned in late October.

Regarding the toxins analyses, neurotoxins (saxitoxin and gonyautoxin) were not detected in cyanobacterial samples collected during October 2004. On the other hand, microcystin was found in both water (ranging from $28-45 \mu \mathrm{g} . \mathrm{L}^{-1}$ ) and natural cyanobacterial samples (138 to $445 \mu \mathrm{g} . \mathrm{g}^{-1}$ dry weight freeze-dried cyanobacteria). Anabaena crude extracts prepared from the cyanobacterial material collected in the reservoir caused acute toxicity to both cladocerans and mice (Sotero-Santos et al., 2008), indicating that toxins released are potentially capable of killing aquatic invertebrates, fish and eventually other animals such as capybaras, herons and other birds which could drink water from reservoir. Currently the Monjolinho Reservoir has as function to improve or beautify the landscape of the UFSCar campus and it has been used as water supply only for wildlife consequently the water quality should be environmentally monitored and preserved. Detecting the occurrence of a toxic bloom in an aquatic ecosystem is only a first step in researching this phenomenon. Additional efforts must be made to develop environmentally correct strategies for eutrophication control in reservoirs such as Monjolinho.

Acknowledgements: We are grateful to Fundação de Amparo à Pesquisa do Estado de São Paulo (Processes 01/13213-5 and 02/08341-7) for financial support and a fellowship during the course of this work.

\section{REFERENCES}

ABOAL, M. \& PUIG, M. A., 2005, Intracellular and dissolved microcystin in reservoirs of the river Segura basin, Murcia, SE Spain. Toxicon, 45: 509-518. doi:10.1016/j.toxicon.2004.12.012

ALAM, M. G. M., JAHAN, N., THALIB, L., WE, I. B. \& MAEKAWA, T., 2001, Effects of environmental factors on the seasonally change of phytoplankton populations in a closed freshwater pond. Environ. Int., 27: 363-371. doi:10.1016/S01604120(01)00087-3

ANAGNOSTIDIS, K. \& KOMÁREK, J., 1988, Modern approach to the classification system of cyanophytes, 3: Oscillatoriales. Arch. Hydrobiol., 80: 237-472.

ANAGNOSTIDIS, K. \& KOMÁREK, J., 1989, Modern approach to the classification system of cyanophytes, 4 - Nostocales. Arch. Hydrobiol., 80: 237-472.

APHA, American Public Health Association, 1995, Standard Methods for the Examination of water and wastewater, $16^{\text {th }} \mathrm{ed}$. APHA, Washington.

BIANCHINI Jr., I. \& ANTONIO, R. M., 2000, Formação anaeróbica de gases dos sedimentos da lagoa do Infernão e do reservatório do Monjolinho. In: J. E. Santos \& J. S. R. Pires (orgs.), Estudos integrados em ecossistemas - Estação Ecológica do Jataí. Rima, São Carlos, p. 685-694.

CALIJURI, M. C., DOS SANTOS, A. C. A. \& JATI, S., 2002, Temporal changes in the phytoplankton community structure in a tropical and eutrophic reservoir (Barra Bonita, SP - Brazil). J. Plankton Res., 24: 617-634. doi:10.1093/plankt/24.7.617

CHORUS, I., FALCONER, I. R., SALAS, H. J. \& BARTRAM, J., 2000, Health risks caused by freshwater cyanobacteria in recreational waters. J. Toxicol. Environ. Health, 3: 323-347. doi:10.1080/109374000436364

DELLAMANO-OLIVEIRA, M. J., VIEIRA, H., ROCHA, O., COLOMBO, V. \& SANT'ANNA, C. L., 2008, Phytoplankton taxonomic composition and temporal changes in a tropical reservoir. Fund. Appl. Limnol./Arch. Hydrobiol., 171: 27-38. doi: 10.1127/1863-9135/2008/0171-0027.

DOWNING, J. A., WATSON, S. B. \& MCCAULEY, E., 2001, Predicting cyanobacteria dominance in lakes. Can. J. Fish. Aquat. Sci., 58: 1905-1908. doi:10.1139/cjfas-58-10-1905

GIANI, A., BIRD, D., PRAIRIE, Y. T. \& LAWRENCE, J. F., 2005, Empirical study of cyanobacterial toxicity along a trophic gradient of lakes. Can. J. Fish. Aquat. Sci., 62: 2100-2109. doi: 10.1139/f05-109

GOLTERMAN, H. L., CLYMO, R. S. \& OHNSTAD, R., 1978, Methods for physical and chemical analysis of freshwater. $2^{\text {nd }}$ ed., Blackwell Sci. Publ., Oxford, 213p. IBP Handbook, 8. 
HINO, K., SIMONATO,A. D. \& HATANAKA, T., 1984, Preliminary limnological study in Monjolinho reservoir. Cienc. Cult., 36: 1402-1407.

HOEK VAN DEN, C., MANN, D. G. \& JAHNS, H. M., 1995, Algae: an introduction to phycology. Cambridge University Press, 644p.

IBELINGS, B. W. \& CHORUS, I., 2007, Accumulation of cyanobacterial toxins in freshwater "seafood" and its consequences for public health: a review. Environ. Pollut., 150: 177-192. doi:10.1016/j.envpol.2007.04.012

KOMÁREK, J. \& ANAGNOSTIDIS, K., 1999, Chroococcales. In: A. Ettl., J. Gerloff, H. Heynig \& D. Mollenhauer (eds.), Süßwasserflora von Mitteleuropa. G. Fischer Verlag, Stutgart.

KOROLEFF, F., 1976, Determination of nutrients. In: K. Grasshoff (ed.), Methods of seawater analysis. Verlag Chemic Weinheim, New York, p. 117-181.

KOTAK, B. G., LAM, A. K. Y., PREPAS, E. E. \& HRUDEY, S. E., 2000, Role of chemical and physical variables in regulation microcystin-LR concentration in phytoplankton of eutrophic lakes. Can. J. Fish. Aquat. Sci., 57: 1584-1593. doi:10.1139/ cjfas-57-8-1584

LOBO, E. \& LEIGHTON, G., 1986, Estruturas de las fitocenosis planctônicas de los sistemas de desembocaduras de rios y esteros de la zona central de Chile. Rev. Biol. Mar., 22: 1-29.

MACKERETH, S. J. H., HERON, J. \& TALLING, J. F., 1978, Water analysis: some revised methods for limnologists, Freshwater Biological Association Scientific Publication, Wilson and Sons, Kendal, 117p.

MUR, L. R., SKULBERG, O. M. \& UTKILEN, H., 1999, Cyanobacteria in the environment. In: I. Chorus \& J. Bartram (eds.), Toxic cyanobacteria in water. A guide to their public health consequences, monitoring and management. E and FN Spon, London, p. 15-37.

NOGUEIRA, M. G. \& TUNDISI, T. M., 1994, Limnologia de um sistema artificial raso (Represa do Monjolinho - São Carlos, SP). I. Dinâmica das variáveis físicas e químicas. Rev. Bras. Biol., 54: 147-159.

NOGUEIRA, M. G. \& TUNDISI, T. M., 1996, Limnologia de um sistema artificial raso (Represa do Monjolinho - São Carlos, SP). II. Dinâmica das populações planctônicas. Acta Limnol. Bras., 8: $149-168$.

NUSH, E. A., 1980, Comparison of different methods for chlorophyll and phaeopigment determination. Arch. Hydrobiol., 14: 14-36.

OCHOA-DE-ALDA, J. A. G., TAPIA, M. I., FRANCK, F., LLAMA, M. J. \& SERRA, J. L., 1996, Changes in nitrogen source modifies distribution of excitation energy in the cyanobacterium Phormidium laminosum. Physiol. Plantarum, 97: 69-78. doi:10.1111/j.1399-3054.1996.tb00480.x

PIELOU, E. C., 1975, Ecological diversity. Willey-Interscience, New York, 385p.

REYNOLDS, C. S., 1997, Vegetation processes in the pelagic: a model for ecosystem theory. Oldendorf/ Luhe Ecology Institute, Germany, 371p. Excelence in Ecology 9.

REYNOLDS, C. S., 1999, Phytoplankton assemblages in reservoirs. In: J. G. Tundisi \& M. Straskraba (eds.), Theoretical reservoir ecology and its applications. Brazilian Academy of Sciences,
International Institute of Ecology/Backhuys Publishers, p. 439-456.

ROUND, F. E., CROWFORD, R. M. \& MANN, D. G., 1990, The diatoms: biology and morphology of the genera. Cambridge University Press, New York, 747p.

SELEGHIM, M. H. R. \& GODINHO, M. J. L., 2004, Peritrich epibiont protozoans in the zooplankton of a subtropical shallow aquatic ecosystem (Monjolinho Reservoir, São Carlos, Brazil). J. Plankton Res., 26: 501-508. doi:10.1093/plankt/fbh055

SHANNON, C. E. \& WIENNER, W., 1963, The mathematical theory of communication. University of Illinois Press, Urbana.

SMITH, V. H., 1983, Low nitrogen to phosphorus ratios favors dominance by blue-green algae in lake plankton. Science, 221: 69-671. doi: 10.1126/science.221.4611.669

SMITH, J. L., BOYER, G. L. \& ZIMBA, P. V., 2008, A review of cyanobacterial odorous and bioactive metabolites: impacts and management alternatives in aquaculture. Aquaculture, 280: 5-20. doi:10.1016/j.aquaculture.2008.05.007

SOTERO-SANTOS, R. B., SOUZA E SILVA, C. R., VERANI, N. V. \& ROCHA, O., 2006, Toxicity of a cyanobacteria bloom in Barra Bonita Reservoir (Middle Tietê River, São Paulo, Brazil). Ecotoxicol. Environ. Safe, 64: 163-170. doi:10.1016/j. ecoenv.2005.03.011

SOTERO-SANTOS, R. B., DELLAMANO-OLIVEIRA, M. J., CARVALHO, E. G. \& ROCHA, O., 2008, Composition and toxicity of a cyanobacterial bloom in a tropical reservoir. Harmful Algae, 7/5: 590-598. doi:10.1016/j.hal.2007.12.017

TUNDISI, J. G., ARANTES, J. D. \& MATSUMURA-TUNDISI, T., 2002, The Wedderburn and Richardson numbers applied to shallow reservoirs in Brazil. Verh. Internat. Verein. Limnol., 28 : 663-666.

TUNDISI, J. G., MATSUMURA-TUNDISI, T. \& ABE, D. S., 2008, The ecological dynamics of Barra Bonita (Tietê River, SP, Brazil) reservoir: implications for its biodiversity. Braz. J. Biol., 68: 1079-1098.

UTERMÖHL, H., 1958, Zur Vervollkomnung der quantitativen Phytoplankton-methodik. Verh. Int. Ver. Limnol., 9: 1-38.

VON RÜCKERT, G. \& GIANI, A., 2004, Effect of nitrate and ammonium on the growth and protein concentration of Microcystis viridis Lemmermann (Cyanobacteria). Rev. Bras. Bot., 27: 325331. doi: 10.1590/S0100-84042004000200011

WATSON, S. B., CHARLTON, M., RAO, Y. R., HOWELL, T., RIDAL, J., BROWNLEE, B., MARVIN, C. \& MILLARD, S., 2007, Off flavours in large water bodies: physics, chemistry and biology in synchrony. Water Sci. Technol., 55: 1-8. doi:10.2166/ wst.2007.155

WETZEL, R. G. \& LIKENS, G. E., 1991, Limnological Analysis. Springer-Verlag, New York, 391p.

WIEGAND, C. \& PFLUGMACHER, S., 2005, Ecotoxicological effects of selected cyanobacterial secondary metabolites a short review. Toxicol. Appl. Pharmacol., 203: 201-218. doi:10.1016/j. taap.2004.11.002

ZURAWELL, R., CHEN, H., BURKE, J. \& PREPAS, E., 2005, Hepatotoxic cyanobacteria: A review of the biological importance of microcystins in freshwater environments. J. Toxicol. Environ. Health, 8: 1-37. doi: 10.1080/10937400590889412 